\title{
Number System in Arabic and English: A Comparative Analysis
}

\author{
Mohamed .A ${ }^{1}$, S. A. Shanavas ${ }^{2}$ \\ ${ }^{1}$ Associate Professor (Retired), E.M.E.A College, Kondotty \\ ${ }^{2}$ Associate Professor, Dept. of Linguistics, University of Kerala
}

Unlike English and many other languages, Arabic has three numbers: singular, dual and plural. Dual are morphologically marked in Arabic whereas in English the number two plus plural is used to mark the dual. For example two cities, two buildings etc are used while in Arabic 'madiinataani' 'binaa'aani' are used instead of 'ithnataa- mudn-in or ithnataaabniyat-in'. In respect of number, Sanskrit is similar to Arabic.

\section{Dual Formation in Arabic}

In order to form dual in Arabic, a dual suffix is added to a singular stem e.g. مدنة+آن=مدينتان 'madiinat +-aani = 'madiinat-aani'. ( two cities). The suffix -aani or ayni depending on case will be used to form dual. If the noun is in nominative case, -aani is used. If it is in accusative or genitive case -ayni is used to mark the dual number.WaSalasafiinaani وصل سفيران two ambassadors arrived.'baynasafiirayni بين سفيرينbeween two ambassadors. Zaaruusafiiraynivisthey visited two ambassadors. The word 'safiiraani' in the first example is the subject of the verb waSala and is in nominative case. But in the second example the word 'safiirayni' is the second term of an annexation structure and in genitive case. The same word in the third example is in accusative case as it is the object of the verb 'zaaruu'. The rule is applicable only if the letters in the base word are regular ( sound).e.g.rajlun رجل 'man' rajulaani رجلانttwomen', or defective منقوصة) with 'ya' ending preceded by kasra e.g. al-qaaDii ألقاضى judge +aanivقاضيانqaaDyaani’ two judges.

If the base word is defective (مقصورة)with the ending of alif preceded by fatHa, there are two types of duals: in one of which the alif is to be changed into 'ya' $\mathbf{}$. It occurs in three cases: one where the alif occurs after three letters as in 'Hublaa' pregnant the dual of which is حبليان'Hublayaani' two pregnant women. In the second case the alif which occurs as the third letter is a substitute of 'ya' 'fataa' young man, the alif is to be changed into sin the dual form e.g. دل معه السّن فتيان 'daxalama ahu -1 ssijnafatayaani' 'two young men entered the jail with him'. The third case is that where alif is not a substitute of 'ya' $\checkmark$ but is used for prolongation asin متى 'Mataa' which is used as a proper noun. Its dual form is 'matayaani'. The second type is that where 'alif' is to be changed into 'waa' g which occurs in two cases: the asif is a substitute of 'wa' as in ' 'aSa' stick

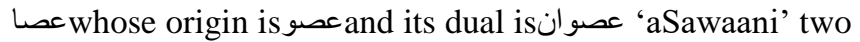
sticks or the alif is not the substitute of 'waa' and is not used لا Ladaif it is used as a proper noun لدى.Ladongation e.g LLadawaani. Nouns ending with the feminine markersltake a 'waa' و before the suffix.e.g. حرباء : حرباوان chameleon. The final $\checkmark$ deleted in some nouns will be restored before the

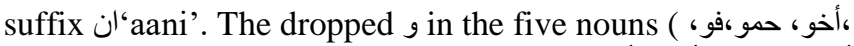

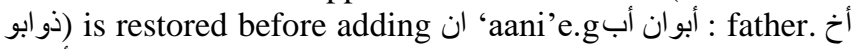
أخوان: brother. If the feminine markerömarbuuTa is added to قطّة : . e.g singular noun, it will be changed into regular ت ت ت قطنانcat .' t' marbuuTa is turned into the regular ت ت

\section{Plural Formation In Arabic}

There are two types of plurals in Arabic: the regular and irregular. The regular type is known a جمع سالم jam'saalim where a suffix ؤuuna is added to the singular form if the noun is in nominative case. If it is in accusative or genitive case the suffix ئين is added to the stem. E.g مسلم :مسلمون/مسلمين /muslim-un : muslimuuna / muslimiina / Mualims.

- In order to mark the soundfeminine plural آت is added to the singular form e.g. مسلمات/ muslimaat/ Muslim women. The irregular plural which is known as جمع التكسير (the broken plural) are very many in Arabic. They are known as broken plural because unlike sound plural, the structure of the singular form is not preserved in the plural either by addingsomething as in صنو: صنوان Sinw-un : Sinwan-un / one of twin brothers or subtracting as in تخمة: تخم-tuxmat: tuxam' 'indigestion' or changing the singular as in l'asad: 'usd 'lion' or by changing the form coupled with addition as inrajul: rijaal رجل:رجال 'man' or changing is coupled with subtraction as رسول: رسل:رجل messenger. ( ibnu-Hishaam,264). The most common broken plural patterns are listed here under triptote and diptote categories.

1) أفعل /af'ul/ This pattern is used as a plural for fa' 1 as a noun having the sound 'ayn' irrespective of its 'laam' being sound or defective by كلب'ya' or و e.g. 'kalb dog'jarw'جرو, ظبلى'deer. The plubal form of a yun أعين'eyes' is irregular. This is the pattern for a feminine noun having four original letters ,the third of

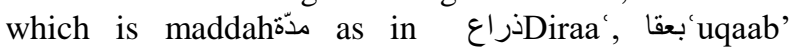
forearm, eagle.

2) أفعال //'af'aal/ This pattern is for trilateral noun to which cannot be the plural form as its عين أفعل e.g

3) أفعلة $3 /$ af ila/ It is the plural of a masculine quadriteral noun whose third letter is maddahoّم e.g. طعام :اطعة food أرغفة رغيف : loaf of bread

4) فتى: فتية ' فعلة /fi ' la/ It is the plural form of 'fatan

5) فعلة5/fu'ala/ It is the regular plural form for the adjective of human beings on the pattern فاعل whose قاض :قضاة ، غاز :غز اة، رام:رماة 'laam’ is defective as in 


\section{International Journal of Science and Research (IJSR) ISSN (Online): 2319-7064}

Index Copernicus Value (2013): 6.14 | Impact Factor (2014): 5.611

6) فعلة /fa' ala/ It is used as plural of an adjective ofhuman being whose 'laam' is sound as in ساحر :سحرة،سافر:سفرة ،بارّ:بررة

7) فلعلى passive participle in the pattern 'fa 'iil' as in ،رحسى 'جرى اسبر:أسرى، قتيل:قتلنجريح

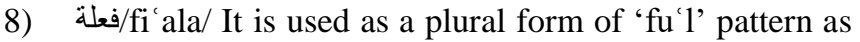

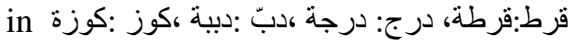

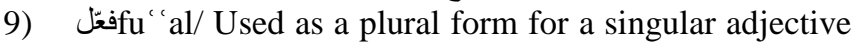
حائض : حائض on the pattern 'faa 'il' or ' faa 'ila' as in حسيّنائحة :نوّة:

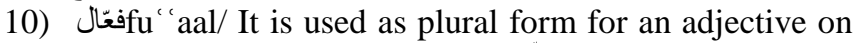

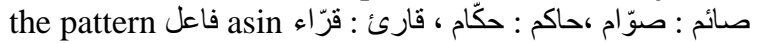

11) فعال/fi 'aal/ used as plural for thirteen singular forms (

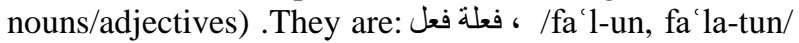

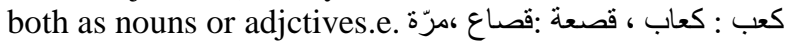
فعل،فعلة :مرار /fa'al-un, fa'alat-un/ that is not derived

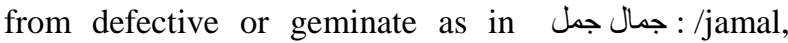
jimaal, جبال : جبل , camelabal: jibaal. moutain, ثمار ثمرة : ثمرة :

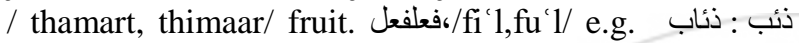

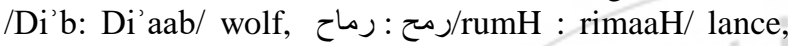

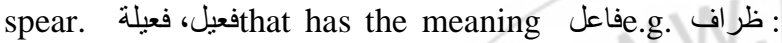

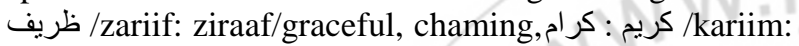
kiraam/ noble.

فر افشريف / shariif: shiraaf/honorable.

/fa'laan/ as an adjective and its feminine

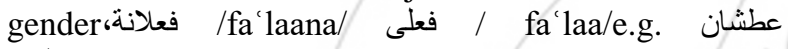
فطاش:/'aTshaan: 'iTaash فعلان/thirasty'laan/ as an adjective and its feminine gender فعلان/ فعلانة/ fu laana/ خمصان :خماص/xumSaan: ximaaS/ lean, slim.

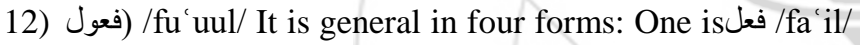
e.g. نمر : نمور/ namir, numuur /leopard, tiger, and the remaining three are the trilateral noun the "ayn' of which has 'sukuun' and its 'fa'has fatHa as in فلس : فلوس : /fals:fuluus/ orkasra as in ضرس : ضروس 'Dirs: Duruus/ or Damma as in جنود : جند /jund:junuud/ army.

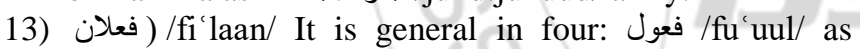

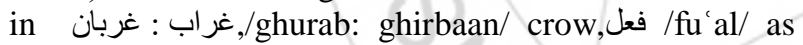

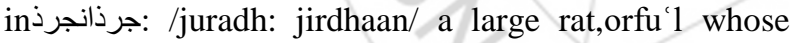

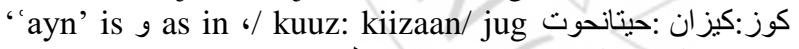

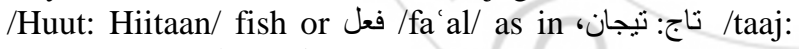

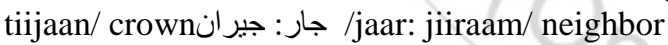

14) فعلان/ fu laan / plural in this pattern is used in a noun on the pattern فعل / fa'l / as ظهر: ظهران/Zahr: Zuhraan/

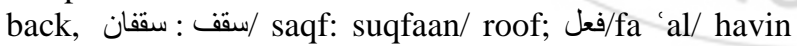

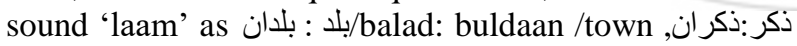
/dhakar: dhukraan / a male

15) فعلاء/fu'alaa' / It is regular in فعيل/fa 'iil / having the

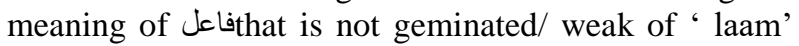

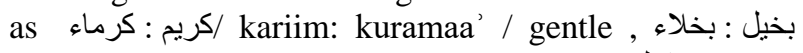

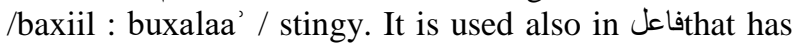

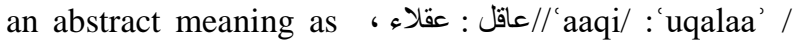
intelligent/ شاعر: شعر اءshaaa 'ir: shu'araa' /poet.

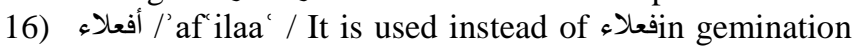

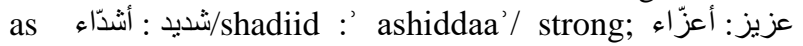
/'aziiz :'a'izzaa' / powerful; mighty; respected. In the defective also ,it is used as اوليَّ/:waliyy : ' auliyaa' / /غنىّ : أغنياء/ghaniyy ;' aghniyaa' / rich.

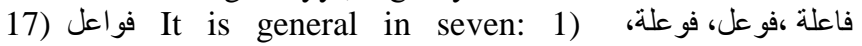

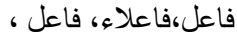

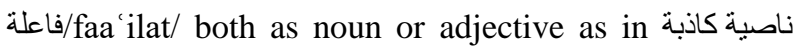
The plural of 'naaSiyat' is نو اصنئة ( ألعلق) 'ThawaaSii / forelock.

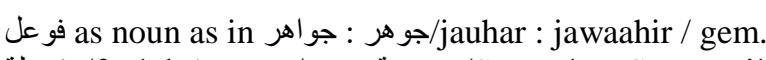

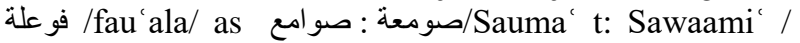
monastery.

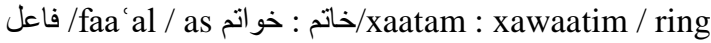

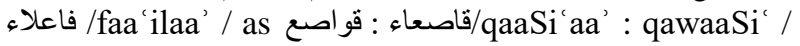
a type stone.

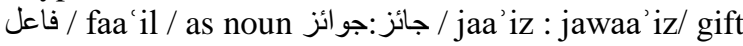
فاعل as a feminine adjective as in حائض : حوائض / Haa'iD

: Hawaa'iD/a lady who menstruates. : / فوالقالق / Taaliq: Tawaaliq / devorsed.

18) فعائل (ف) It can generally be used in all feminine

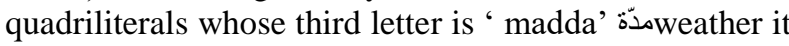
is marked by 'ta' marbuuta as in سحابة : سحائب ، سدة /saHaabat: saHaa' $\mathrm{ib} / \mathrm{cloud}$ or not marked for feminine gender but is used a feminine as in عجوز : عجائز 'ajuuz: 'ajaaiz/ old woman.

19) /fa'aalii / This plural form is generally used in seven singular patterns which are listed below:

1. فعلاء/fa 'laa / as / عذارى عذر : /adhraa' : 'adhaarii / a virgin.

2. فعلاة / موماة : مو ام /maumaat :mawaammin / a

large desert.

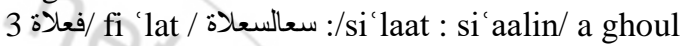
4. هبرية :هبار / fi ' فعلاد/ hibriyat: habaarin/ a rough ground.

5. فعلوة /fa ' luwat/as / مرقوة : عراق 'arquwat: 'araaqin / a stick that is put horizontally on a bucket.( 276, AuDaH 1 masaalik ).

20) / عذر اء : عذارى 'adhraa' : 'adhaarin / a vergin.

1 فتوى: فتاوى /fatwa: fataawaa / a formal legal opinion. دعوى : دعاوى : دعاوى/da'waa : da'aawaa / a claim.

2. / أبلى :حبالى /Hublaa: Habaalaa/ a pregnant woman. فنتى : خناثى / xunthaa : xayaathaa / a hermaphrodite.

3 الحير ان : حيارى Hayraan : Hayaaraa / perplexed.

21 / fa' aaliyy / . It is generally used in every trilateral substantives/adjectives the last letter of which is 'ya' $\mathbf{s}$ having 'shadda' not for 'nisba' as

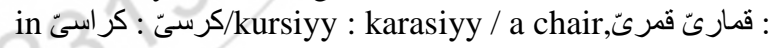
/qumriyy: qamaariyy / a variety of turtledove.

21) فعالل which are quadrilateral or quinqueliteral originally or by increase as in ثعلب :ثعالب tha lab : tha'aalib / a fox. /Difda': Dafaadi'/ a frog.

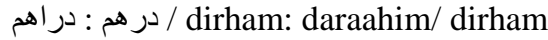

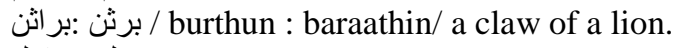
جدول :جداول / زلر / jadwal: jadaawil/ a streamlet.

The following are the examples of quinqueliteral substantives

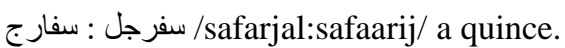

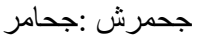

In quinqueliterals the fifth letter will be dropped. If the singular contains five letters, the fifth letter as a rule will be dropped in the plural. As the broken plurals are many, it is better to learn singular and plural as a pair. Compared to English, Arabic plurals are much more though they are rule bound. 


\section{Plural Formation of Nouns in English}

(1) Most nouns in English form plurals by taking $-\mathrm{s}$ or -es. A book some books

A house a few houses

(2) A noun ending in $-y$ and preceded by a consonant makes the plural with -ies.

A cry cries of helpless people

A city some cities of attraction.

(3) There are some irregular forms of plural.

Woman women

Child children

Tooth teeth

Leaf leaves

Fungus fungi

(4) Same form for both singular and plural.

Sheep sheep

Fish fish

Species species

(5) Some nouns have plural forms but they take singular verbs.

News this is a concocted news

Mathematics Mathematics is an interesting subject.

Billiards billiards is a popular game.

(6) Some nouns in English have plural forms and they take plural verbs.Trousers, jeans and glasses (spectacles) are such words. The rules of pluralisation of English nouns can be summarized as follows:

[Affixation(adding -s/-es/-ies )/internal changes /zero morpheme ]

\section{Comparison and Contrast}

Affixation for plural formation is found both in Arabic and English e.g. طالب :طالبون ، طالبين/Taalib: Taalibuuna , Taalibiina / student: students.

Internal changes as in tooth and teeth are also found in both e.g. كريم :كر ام kariim : kiraam/ gentle.

Zero morpheme as sheep : sheep is found only in English not in Arabic. There are only two numbers in English: singular and plural. For dual two plus plural form ( e.g. two tribes ) is used in English. But in Arabic there are three numbers: singular, dual and plural. In Arabic affixation differs in accordance with difference in cases e.g. for nominative case 'uuana' is added to the singular whereas in accusative/ genitive case ' iian' is added. In English there is no case difference.

\section{References}

[1] Al -Ansari,IbnHisham. AuDaHulMasaalikilaa 'Alfiyaibn Maalik ,Dar al Talaa'i',2004,Cairo.

[2] Ryding, Karin. C. A Reference Grammar of Modern Standard Arabic,Cambridge University Press,2005.
[3] Wright,W. A Grammar of the Arabic Language,Librairie Du Liban,1974,Beirut.

[4] Alosh,Mahdi.Using Arabic A Guide to Contemporary Usage,Cambridge University Press, 2005. 